\title{
EFFICACY OF TRITICUM AESTIVUM (WHEATGRASS) AGAINST ARSENIC INDUCED HEPATIC DAMAGES
}

\author{
ANITA NAREDA*, MADHU KUMAR \\ Department of Zoology, University of Rajasthan, Cell and Molecular Biology Laboratory, Jaipur, Rajasthan, India. \\ Email: anitamishra1103@gmail.com
}

Received: 27 December 2020, Revised and Accepted: 16 February 2021

\section{ABSTRACT}

Objective: Arsenic is a metalloid element that is one of the most important global environmental toxicants and is found in both organic and inorganic forms. The present study was designed to find out the preventive role of Triticum aestivum against arsenic-induced oxidative stress in the liver of Swiss albino mice

Methods: The protective role of T. aestivum (Wheatgrass) against arsenic-induced hepatic damages was investigated in adult Swiss albino mice. The animals were divided in to four groups: (i) Control group - only vehicle (double distilled water), (ii) T. aestivum treated group-20 ml/kg body weight (b.wt.), orally (iii) $\mathrm{NaAsO}_{2}$ treated group- $4.0 \mathrm{mg} / \mathrm{kg}$ b.wt., and orally (iv) combination group - T. aestivum leaves extract (20 ml/kg b.wt.) and $\mathrm{NaAsO}{ }_{2}$ $(4.0 \mathrm{mg} / \mathrm{kg} / \mathrm{b} . w \mathrm{t}$.). Bodyweight and liver weight were measured in the process. Activities of marker enzymes such as alkaline phosphatase (ALP), Glutamic oxaloacetic transaminase, and glutamic pyruvic transaminase were measured in serum. Activities of lipid peroxidation (LPO), glutathione (GSH), and Lactate dehydrogenase (LDH) were measured in the liver.

Results: The results indicated that arsenic intoxication caused a decrease in b.wt. and liver weight. Arsenic intoxication significantly increased hepatic LPO, Serum Glutamate Oxaloacetate Transaminase (SGOT), and Serum Glutamate Pyruvate Transaminase (SGPT) activities whereas significantly decreased hepatic GSH, hepatic $\mathrm{LDH}$, and serum ALP activities. Combined treatment of T. aestivum and $\mathrm{NaAsO}_{2}$ showed: (i) An increase in body and liver weight, (ii) a significant decrease in LPO, SGOT, and SGPT activities, (iii) an elevation in GSH content, LDH, and serum ALP activities, as compared to $\mathrm{NaAsO}_{2}$ treated group.

Conclusion: Thus, T. aestivum was found to be protective against arsenic-induced hepatic damages.

Keywords: Arsenic, Triticum aestivum, Lipid peroxidation, Glutathione, Serum glutamate oxaloacetate transaminase, Lactate dehydrogenase.

(C) 2021 The Authors. Published by Innovare Academic Sciences Pvt Ltd. This is an open access article under the CC BY license (http://creativecommons.org/ licenses/by/4.0/) DOI: http://dx.doi.org/10.22159/ajpcr.2021v14i4.40639. Journal homepage: https://innovareacademics.in/journals/index.php/ajpcr

\section{INTRODUCTION}

Arsenic, a highly poisonous metalloid, is one of the natural constituents of the earth's crust. It is found in various concentrations in all ecosystems. Arsenic can enter the body through inhalation or consuming arsenic-contaminated food and drinking water or through skin contact [1]. Arsenic ingested with contaminated food and drinking water is mainly absorbed through the small intestine. Arsenic exerts its toxicity by inactivating up to 200 enzymes, especially those involved in cellular energy pathways and DNA synthesis and repair [2]. Exposure to arsenic may cause severe pathological problems such as arsenicosis, cardiovascular diseases, cerebrovascular diseases, and congenital malformations in offsprings as well as cancers of different organs [3,4]. Arsenic exposure stimulates the release of iron from ferritin and the resulting free iron is considered as a potent inducer of the formation of reactive oxygen species (ROS) through Fenton-type reaction [5]. Arsenic exposure produces a large amount of ROS that can impair the cellular antioxidant defense system and simultaneously damage the cellular ingredients such as lipids, proteins, and DNA [6].

Natural antioxidants are beneficial to mitigate chemical-induced oxidative damages [7,8] and are prominent immune boosters [9]. The young grass (7-9 days old) of Triticum aestivum commonly called Wheatgrass (Family: Gramineae) is called superfood as it provides overall nourishment to the body [10]. Phytochemical investigation of wheatgrass has shown that it is a rich source of carbohydrates, amino acids, secondary metabolites, chlorophyll, and Vitamin C [11].
It is rich in chlorophyll content and essential vitamins, minerals, vital enzymes, amino acids, and dietary fiber [12]. Runjala and Murthy [12] have also stated that the medicinal value of T. aestivum might be due to the presence of biologically active compounds and minerals in it and its antioxidant potential, which is attributed to its high bioflavonoid content. Medicinal properties of T. aestivum are due to its rich content of chlorophyll, antioxidants, minerals, and phytochemicals [13]. Qualitative analysis of phytochemicals confirms the presence of alkaloids, flavonoids, tannins, terpenoids, steroids, and glycosides in T. aestivum extract [14]. Ferruzzi et al. [15] have demonstrated that chlorophyll derivatives present in dietary supplements have antioxidant and antimutagenic activities. Chlorophyll is found to have potential antiinflammatory, anticancer, antioxidant, anti-aging, and anti-mutagenic properties $[16,17]$. The present investigation has been undertaken to elucidate the biochemical mechanism associated with the hepatoprotective role of T. aestivum against arsenic-induced toxicity in the liver of Swiss albino mice.

\section{METHODS}

\section{Animals}

Random bred, male Swiss albino mice (Mus musculus), 6-8 weeks old (average body weight [b.wt.] $22 \pm 2$ g) were used for experiments, according to animal ethical committee approval. Animals were maintained according to the standards of the animal ethical committee. These animals were maintained in the animal house (Department of Zoology, University of Rajasthan) at temperatures of $24 \pm 3^{\circ} \mathrm{C}$ and light of 14:10 h of light and dark. These animals were housed in polypropylene 
cages and fed standard mice feed on Hindustan Limited, Delhi. Tap water was provided to the animals ad libitum, and tetracycline was given monthly to the animals against infections.

\section{Plant material}

T. aestivum (RUBL No. 20597) was grown in an earthen pot under controlled conditions of temperature and light. Fresh leaves of wheatgrass were cut from 7-day old plants. The juice was extracted from its leaves after washing, air drying, and homogenizing in a pestle mortar and finally filtered through a sterile gauge cloth.

\section{T. aestivum drug tolerance study and optimum dose selection}

T. aestivum fresh leaves juice (without adding water) was given to animals at different dose levels (5, 10, 20, 40, and $80 \mathrm{ml} / \mathrm{kg}$ b.wt.) by oral gavage for 30 days, in the morning. The optimum dose selection of T. aestivum leaves extract was done by determining the level of LPO and GSH (Tables 1 and 2). Out of different doses, $20 \mathrm{ml} / \mathrm{kg}$ b.wt. was selected for the experimental protocol as maximum $\mathrm{GSH}^{*}$ and minimum LPO* level was observed at this dose.

Determination of radical scavenging activity of T. aestivum using 1,1-diphenyl-2-picryl hydrazyl radical (DPPH) assay

Radical scavenging activity of leaves' extract against stable DPPH was determined spectrophotometrically. The DPPH assay was carried out as described by Cuendet et al., 1997 [18]. In the present investigation, $T$. aestivum extract was observed to have good radical scavenging activity with the inhibition of $12 \%$ at a $1 \mathrm{ml} / \mathrm{ml}$ (concentration of the extract in methanol), as reported by Arya and Kumar [19].

\section{Toxicant}

Arsenic in the form of sodium arsenite, $\mathrm{NaAsO}_{2}$ was used for the present study. It was obtained from HiMedia India Limited, Mumbai. It was dissolved in double distilled water (DDW) and administered orally $4 \mathrm{mg} / \mathrm{kg}$ b.wt./day for 30 days.

\section{Experimental protocol (design of experiment)}

Swiss albino mice were divided into the following groups.

Group I $(\mathrm{n}=30)$ : The animals were administered only vehicle (DDW, orally, severed as a control for Groups II and III).

Group II $(n=30)$ : The animals were administered only T. aestivum leaves extract $(20 \mathrm{ml} / \mathrm{kg}$ b.wt./day) orally by gavage once daily for 30 days.

Group III (n=30): The animals were administered $\mathrm{NaAsO}_{2}(4 \mathrm{mg} / \mathrm{kg}$ b.wt.) dissolved in DDW orally by gavage once daily for 30 days.
Group IV ( $\mathrm{n}=30)$ : The animals were administered T. aestivum leaves extract ( $20 \mathrm{ml} / \mathrm{kg}$ b.wt., orally) once daily for 10 days. From day $11^{\text {th }}$ animals were given $\mathrm{NaAsO}_{2}(4.0 \mathrm{mg} / \mathrm{kg}$ b.wt., orally in DDW) by oral gavage once daily; after $1 / 2$ $\mathrm{h}$ T. aestivum leaves extract was given once daily. This day was considered as day $0 . \mathrm{NaAsO}_{2}$ and T. aestivum were given to the animals up to 30 days from day 0 .

The animals were weighed and autopsied on 1, 3, 7, 15, and 30 days after the heavy metal or plant extract treatment. The liver was removed, rinsed in cold saline, blotted, weighed, and processed for various biochemical assays. Fresh unhemolysed serum was used for determining transaminases and alkaline phosphatase (ALP) activities.

\section{Biochemical parameters}

Reduced GSH

The GSH level in the liver was determined by the method of Moron et al. [20]. GSH was used as a standard to calculate micromole $\mathrm{GSH} / \mathrm{g}$ tissue.

\section{Lipid peroxidation (LPO) assay}

LPO level in the liver was estimated by the method of Okhawa et al. [21] as thiobarbituric acid reactive substances (TBARS). The concentration of TBARS was expressed as $\mathrm{n}$ moles of malondialdehyde per mg of tissue using 1,1,3,3-tetramethoxypropane as the standard.

$L D H$

LDH activity in the liver was estimated by the "Wroblewski procedure" [22]. Optical Density was measured at 400-500 nm.

\section{Serum ALP}

Commercially accessible kits (Span Diagnostics Ltd., Surat, India) were used to measure serum ALP by Kind and King's method [23]. Optical density was measured in King Armstrong Unit at $510 \mathrm{~nm}$.

Serum glutamate oxaloacetate transaminase (SGOT) and serum glutamate pyruvate transaminase (SGPT)

SGOT and SGPT activities were estimated by the method of Reitman and Frankel [24] using DNPH as a color reagent which can be measured colorimetrically.

\section{Statistical analysis}

Data are expressed as mean \pm S.E. Statistical significance of the difference between groups was determined by Student's t-test [25].

Table 1: Variation in hepatic LPO level ( $\mathrm{n} \mathrm{mol}$ of MDA/mg of tissue) at different dose levels of Triticum aestivum in Swiss albino mice

\begin{tabular}{lllll}
\hline Experimental groups & \multicolumn{2}{l}{ Autopsy intervals in days } & & \\
\cline { 2 - 5 } & Day $\mathbf{1}$ & Day $\mathbf{3}$ & Day 7 & Day 15 \\
\hline Control (DDW) & $3.89 \pm 0.20$ & $3.93 \pm 0.04$ & $3.82 \pm 0.22$ & $3.85 \pm 0.18$ \\
Triticum aestivum (5 ml/kg b.wt.) & $3.95 \pm 0.29$ & $3.56 \pm 0.44$ & $3.12 \pm 0.62$ & $2.99 \pm 0.26$ \\
Triticum aestivum $(10 \mathrm{ml} / \mathrm{kg}$ b.wt.) & $2.92 \pm 0.19$ & $2.70 \pm 0.23$ & $2.63 \pm 0.17$ & $2.48 \pm 0.21$ \\
Triticum aestivum $(20 \mathrm{ml} / \mathrm{kg}$ b.wt.) & $2.63 \pm 0.14$ & $2.14 \pm 0.12$ & $1.99 \pm 0.15$ & $1.87 \pm 0.13$ \\
Triticum aestivum $(40 \mathrm{ml} / \mathrm{kg}$ b.wt.) & $2.87 \pm 0.10$ & $2.43 \pm 0.26$ & $2.27 \pm 0.17$ & $2.14 \pm 0.15$ \\
Triticum aestivum $(80 \mathrm{ml} / \mathrm{kg}$ b.wt.) & $2.60 \pm 0.14$ & $2.51 \pm 0.20$ & $2.28 \pm 0.13$ & $2.32 \pm 0.29$ \\
\hline
\end{tabular}

Table 2: Variation in hepatic GSH content ( $\mu$ mol/gm of tissue) at different dose levels of Triticum aestivum in Swiss albino mice

\begin{tabular}{lllll}
\hline Experimental groups & \multicolumn{2}{l}{ Autopsy intervals in days } & & \\
\cline { 2 - 5 } & Day $\mathbf{1}$ & Day 3 & Day 7 & Day 15 \\
\hline Control (DDW) & $7.87 \pm 0.53$ & $7.36 \pm 0.76$ & $7.97 \pm 0.63$ & $7.90 \pm 0.69$ \\
Triticum aestivum (5 ml/kg b.wt.) & $8.14 \pm 0.49$ & $8.03 \pm 0.74$ & $8.02 \pm 0.34$ & $8.47 \pm 0.81$ \\
Triticum aestivum ( ml/kg b.wt.) & $8.42 \pm 1.15$ & $8.46 \pm 0.84$ & $9.10 \pm 0.75$ & $9.02 \pm 1.00$ \\
Triticum aestivum (20 ml/kg b.wt.) & $9.04 \pm 1.17$ & $8.55 \pm 0.79$ & $9.41 \pm 0.69$ & $9.33 \pm 0.88$ \\
Triticum aestivum (40 ml/kg b.wt.) & $7.98 \pm 0.46$ & $7.82 \pm 0.98$ & $8.67 \pm 0.44$ & $8.80 \pm 0.65$ \\
Triticum aestivum (80 ml/kg b.wt.) & $7.92+0.38$ & $7.86+0.81$ & $8.40+0.24$ & $8.72+0.55$ \\
\hline
\end{tabular}




\section{RESULTS}

\section{B.Wt.}

A non-significant increase in the b.wt. was observed in the T. aestivum treated group as compared to the control (DDW) group. In the $\mathrm{NaAsO}_{2}$ treated group, a reduction in b.wt. was observed from day 1 to day 30 as compared to the control group. In the combination group, a significant increase was observed on days 3,7 , and 15 which became highly significant on day 30 as compared to the arsenic-treated group (Fig. 1a).

\section{Liver weight}

T. aestivum alone did not show any significant alterations in liver weight as compared to the control group. $\mathrm{NaAsO}_{2}$ treated animals showed a reduction in liver weight from day 1 to day 30 as compared to Group I. In the combination group a significant increase in liver weight was observed from day 3 to day 30 as compared to the arsenic-treated group (Fig. 1b).

\section{Reduced GSH}

In the $\mathrm{NaAsO}_{2}$-treated group a significant $(\mathrm{p}<0.01)$ decrease in GSH content was recorded from day 1 to day 30 as compared to the control (DDW) group. T. aestivum alone showed a non-significant increase in GSH level at all autopsy intervals as compared to the control group. The combined treatment of T. aestivum with arsenic caused a highly significant $(\mathrm{p}<0.001)$ elevation in GSH level from day 1 to day 30 as compared to arsenic-treated group (Fig. 1c).

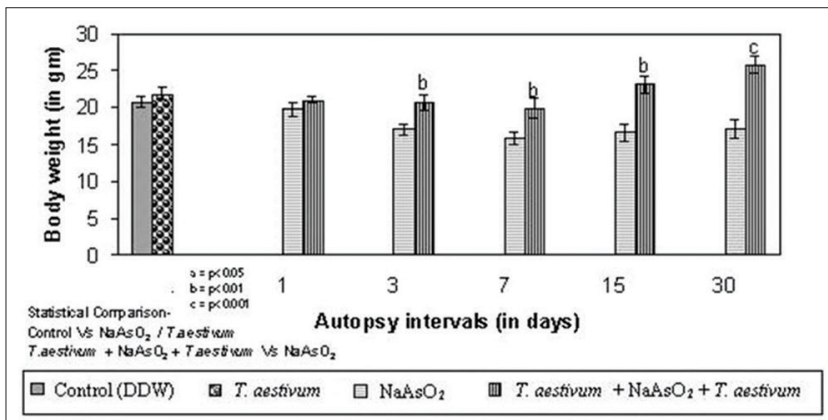

a

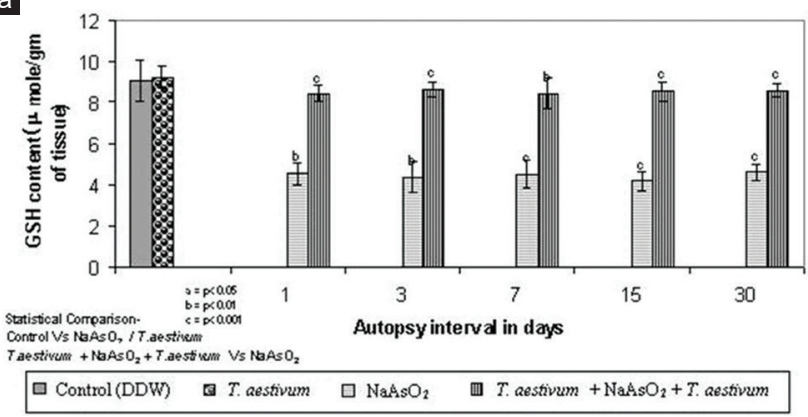

c

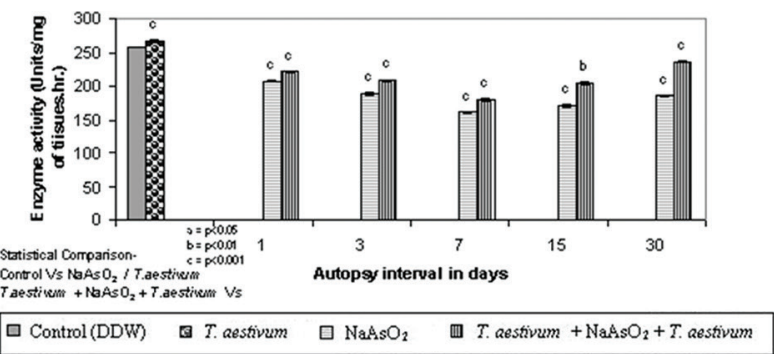

e

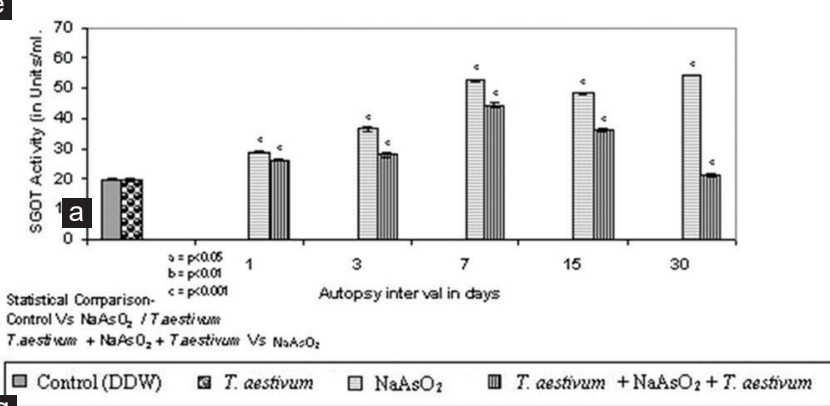

d

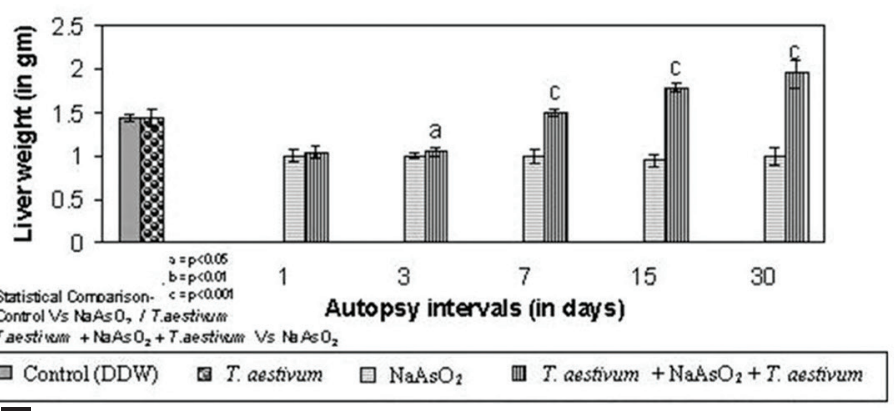

a
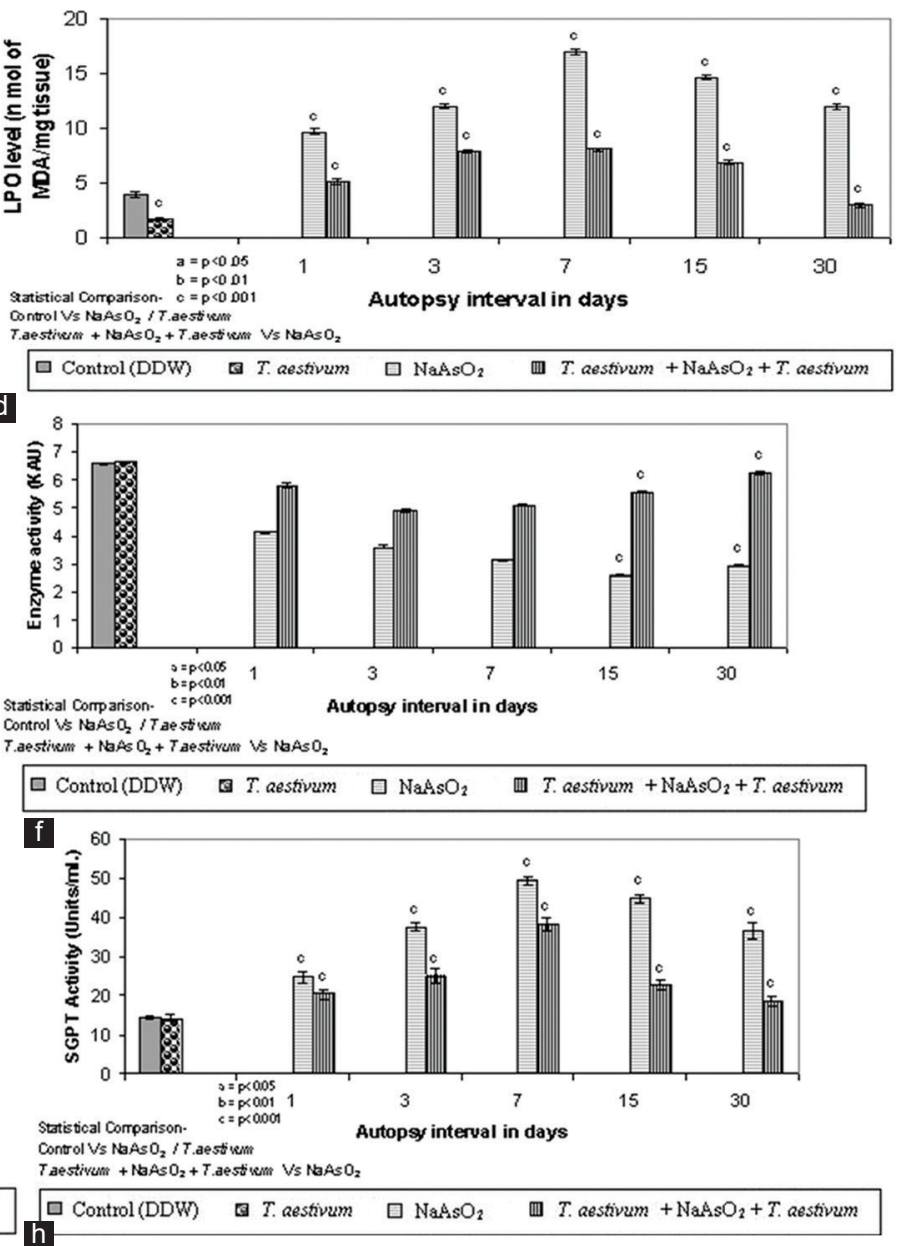

Fig. 1: (a) Variation in bodyweight in different experimental groups. (b) Variation in liver weight in different experimental groups. (c) Variation in glutathione in different experimental groups. (d) Variation in lipid peroxidation in different experimental groups. (e) Variation in lactate dehydrogenase in different experimental groups. (f) Variation in serum alkaline phosphatase in different experimental groups (g) Variation in serum glutamate oxaloacetate transaminase in different experimental groups. (h) Variation in serum glutamate pyruvate transaminase in different experimental groups 
LPO

In the $\mathrm{NaAsO}_{2}$-treated group, a highly significant $(\mathrm{p}<0.001)$ increase in LPO level was noticed at all autopsy intervals when compared to the control (DDW) group. T. aestivum treated group showed a significant decline in hepatic LPO level as compared to control (DDW). The combined treatment of T. aestivum with sodium arsenite showed a highly significant decline $(\mathrm{p}<0.001)$ in hepatic LPO level at all autopsy intervals for the arsenic-treated group (Fig. 1d).

\section{LDH}

A highly significant $(\mathrm{p}<0.001)$ decline in LDH activity was observed in $\mathrm{NaAsO}_{2}$-treated animals as compared to Group I. T. aestivum treated group showed a highly significant $(\mathrm{p}<0.001)$ increase in liver LDH activity as compared to control (DDW). The pre- and post-treatment of T. aestivum with $\mathrm{NaAsO}_{2}$ resulted in a highly significant $(\mathrm{p}<0.001)$ increase in LDH activity throughout the whole experimental period as compared to arsenic-treated animals (Fig. 1e).

\section{Serum ALP}

In the $\mathrm{NaAsO}_{2}$-treated group, a highly significant decline $(\mathrm{p}<0.001)$ in serum ALP activity was observed throughout the whole experimental period. In the T. aestivum treated group, the enzymatic activities were found normal at all autopsy intervals. The combined treatment of $T$. aestivum with arsenic showed a highly significant elevation $(\mathrm{p}<0.001)$ in serum ALP activity at all autopsy intervals for $\mathrm{NaAsO}_{2}$-treated animals (Fig. 1f).

\section{SGOT}

A highly significant elevation $(\mathrm{p}<0.001)$ in SGOT activity was noticed in animals throughout the experimental period in $\mathrm{NaAsO}_{2}$-intoxicated mice. In T. aestivum-treated animals, there were no significant alterations in SGOT activity at all autopsy intervals. However, the combined treatment of T. aestivum with $\mathrm{NaAsO}_{2}$ showed a highly significant decline $(\mathrm{p}<0.001)$ in SGOT activity at all autopsy intervals as compared to the arsenic-treated mice (Fig. 1g).

\section{SGPT}

In $\mathrm{NaAsO}_{2}$-treated animals, a highly significant increase $(\mathrm{P}<0.001)$ in SGPT activity was noticed throughout the experimental period. Treatment with $T$. aestivum showed no alterations in enzymatic activities. The combined treatment of T. aestivum with arsenic showed a highly significant decline $(\mathrm{p}<0.001)$ in SGPT activity from days 1 to 30 for arsenic-intoxicated mice (Fig. 1h).

\section{DISCUSSION}

Arsenic intoxication significantly decreased the b.wt. in mice throughout the whole experimental period as compared to control animals. Other studies have also reported similar results in mice and rats [26-28]. Arsenic intoxication increases permeability and damages intestinal lining which may be responsible for improper absorption of nutrients and loss of appetite in animals [29]. In a study subchronic exposure to low doses of arsenic through drinking water has been shown to alter the systematic physiology of male rats [30].

In the present study, arsenic intoxication produced a significant $(p<0.001)$ decrease in liver weight throughout the experimental period. Arsenic induces cell death (necrosis and apoptosis) in the liver [31]. Arsenic produces hepatocellular necrosis and liver degeneration [32]. Arsenic exposure causes a change in the balance between cell death and proliferation coupled with a robust loss of liver weight [33].

The liver is the major site for the accumulation of arsenic to toxic levels and therefore it is highly susceptible to arsenic damage which is reflected by changes in the activities of several liver enzymes and cellular damage in liver tissue of experimental animals [34]. The present investigation revealed a significant elevation in LPO level in terms of TBARS following $\mathrm{NaAsO}_{2}$ exposure. An increase in the concentration of LPO products is an indication of the involvement of free radicals in particular pathological conditions [35]. These ROS attack the polyunsaturated fatty acids of the fatty acid membrane, initiating a self-propagating chain reaction. The destruction of membrane lipids and the end-products of such LPO reactions are especially dangerous for the viability of cells, even tissues [36]. The most significant effect of LPO in injured cells is the perturbation of membrane (cellular or organelle) structure and function. A radical is any species that contain one or more unpaired electrons present alone in atomic or molecular orbitals. The most reactive radical species to form in living organisms is hydroxyl radical, which can attack any biological molecule present next to them including cellular protein, DNA, and lipids. LPO diminishes membrane fluidity, increases non-specific permeability to ions (Ca2+), and inactivates membrane-bound enzymes [37]. An increase in the cytosolic free $\mathrm{Ca} 2+$ concentration because of increased permeability of plasma membrane has been proposed as a mechanism of oxidative stress-induced cell injury and cell death [38,39].

There is a positive relationship between arsenic exposure and oxidative damage. Arsenic exposure decreases the level of antioxidants present in the cell and increases the level of oxidants. Oxidative damage due to As3+ exposure is more significant than to As5+ [40]. Glutathione is well known for its pivotal role in the intrinsic antioxidant defense system. Arsenic is known to exert at least some of its toxic effects through interaction with sulfhydryl groups, and the non-protein sulfhydryl glutathione (GSH) appears to play an important role in the detoxication of arsenic [41]. GSH is required in the methylation of arsenic by stabilizing the reductive nature of the cell and methylation of arsenic can be a detoxification mechanism that does not permit the As(III) intermediates to accumulate [42]. The present investigation revealed that arsenic intoxication caused a significant decrease in reduced glutathione. Sodium arsenite-induced oxidative damage has been shown to elevate thiobarbituric acid-reactive substances (TBARS) in the liver of rats [43]. LPO is described as one of the mechanisms of arsenic toxicity associated with a concomitant decrease in cellular GSH level in the liver [27,44].

The present study showed a decrease in LDH activity following the exposure to sodium arsenite. Sodium arsenite-induced leakage of lactate dehydrogenase (LDH) has been used to assess the cytotoxicity of arsenic $[45,46]$. LDH release occurs only when cells have ruptured which is indicative of cell death $[47,48]$. An increase in arsenic concentration causes an increase in LDH leakage and a decrease in cell proliferation $[45,49]$.

The results of the present investigation established that arsenic intoxication causes a significant decrease in serum ALP activity and a significant increase in SGOT and SGPT activity. ALP is an enzyme, or more precisely, a family of related enzymes, is produced in bile ducts by lipid membranes of the canalicular zone and sinusoidal membranes of the liver, so any interference in bile flow leads to a decrease in ALP activity $[50,51]$. The decrease in serum ALP activity in the present investigation may be due to damage to the cell membrane caused by $\mathrm{NaAsO}_{2}$. The damage to the cell membrane due to LPO leads to the imbalance between synthesis and degradation of enzyme proteins [52]. Sharma et al. $[27,45]$ also reported that sodium arsenite intoxication caused a significant decline in serum ALP activity in mice. An increase in both SGOT and SGPT is a potential marker of hepatocellular toxicity [53,54]. They leak out through the membrane into the peripheral blood where they can be measured. In the present study, a significant increase in SGOT and SGPT activity in serum indicates liver damage due to arsenic toxicity. Arsenic intoxication causes liver injury and these enzymes leak out of the liver in peripheral blood $[46,55]$.

It has been observed that pre-and post-treatment with T. aestivum (Wheatgrass) protected against arsenic toxicity in Swiss albino mice effectively by exhibiting a significant decrease in hepatic MDA content, SGOT, SGPT, and serum ALP activity and a significant increase in b.wt., liver weight, GSH content, and LDH activity in the liver as compared with the arsenic-intoxicated mice. 
The protective effect of T. aestivum (Wheatgrass) is attributed to its potential antioxidant properties and phytochemical profile. Wheatgrass has been proved to be an effective radical scavenger in different antioxidant assays $[56,57]$. Wheatgrass juice was found to have freeradical scavenging activity when evaluated by DPPH assay, nitric oxide, hydroxyl radical, and good antioxidant activity in mouse liver and brain as determined by FRAP assay and anti-LPO activity [58].

Wheatgrass juice is rich in secondary metabolites which are responsible for its antioxidant activity. Wheatgrass juice is found to have good antioxidant action in various models because it is rich in phenolic compounds, flavonoids, flavonols, and alkaloids [58]. Qualitative phytochemical analysis of wheatgrass leaves extract confirms the presence of various phytochemicals such as alkaloids, flavonoids, tannins, terpenoids, steroids, and glycosides [57]. Wheatgrass has good antioxidant and cytotoxic properties because of phenols and flavonoids present in it [59].

Wheatgrass improves overall nourishment. Experimental results have shown that wheatgrass is a good source of essential nutritional elements such as $\mathrm{Zn}, \mathrm{K}, \mathrm{Na}, \mathrm{Ca}, \mathrm{Mg}, \mathrm{Cl}$, and $\mathrm{Fe}$ in a bioavailable form with potential antioxidant activity [60-62]. It is rich in antioxidants which can overturn LPO and increase GSH activity. In a study done by Shakya et al. [63], wheatgrass has been found to protective against oxidative stress by decrease in LPO and increase in enzymatic and non-enzymatic antioxidants in male albino Wistar rats. Chlorophyll, flavonoids, and Vitamins C and E present in Wheatgrass ( $T$. aestivum) are responsible for their benefits to immunological activity and oxidative stress [64]. Chlorophyll is one of the important pharmacologically active components in wheatgrass and it is found to have significant antioxidant activity which is comparable to ascorbic acid [57]. T. aestivum is potentially rich in chlorophyll, and vital antioxidant enzymes superoxide dismutase (SOD), cytochrome oxidase which converts dangerous free-radical ROS into hydrogen peroxide and an oxygen molecule [65]. In addition to antioxidant potential, indole compounds present in wheatgrass increase the activity of Phase I and Phase II xenobiotic metabolic enzymes in the liver and intestinal mucosa [66].

T. aestivum (Wheatgrass juice) has stimulatory effects on healthy tissue formation, tissue repair system, and healing system of the body $[67,68]$. Wheatgrass has been found to have wound healing activity in Wistar albino rats [69]. Wheatgrass derived polysaccharides protect against hepatic injury and improve the oxidative status of liver tissues in mice [70]. Medicinal plants with a high level of antioxidants provide effective therapy against hepatic damages [71]. Phenolic and polyphenolic compounds are among the most important antioxidants present in the diet and many plants of medicinal value [72,73]. The antioxidant activity of phenolic compounds is due to their ability to quench free radicals by donating a hydrogen atom or an electron to the free radical [74]. T. aestivum (Wheatgrass) has potential pharmacological properties and can be used for hepatoprotective treatment [75].

The protective role of T. aestivum (Wheatgrass) is demonstrated by its normalizing effects on various hepatic enzymes, which suggests that $T$. aestivum may show its modulatory effect by preventing cellular injury and maintaining the GSH level.

The present study suggests that deleterious ROS or lipid peroxides induced by arsenic exposure can be mitigated by T. aestivum (Wheatgrass) extract which is reflected by a significant decline in LPO content and acid and APL, SGOT, SGPT activity, and a significant enhancement in b.wt., liver weight, LDH and GSH content in the liver as compared to the $\mathrm{NaAsO}_{2}$-treated group in Swiss albino mice.

\section{REFERENCES}

1. Rahman M. Arsenic and contamination of drinking water in Bangladesh: A public health perspective. J Health Popul Nutr 2002;20:193-7.

2. Ratnaike RN. Acute and chronic arsenic toxicity. Postgrad Med J 2003;79:391-6.
3. Jin Y, Xi S, Lu C, Li G, Xu Y, Qu C, et al. Arsenic speciation transported through the placenta from mother mice to their newborn pups. Environ Res 2006;101:349-55.

4. Walvekar RR, Kane SV, Nadkarni MS, Bagwan IN, Chaukar DA, D'Cruz AK. Chronic arsenic poisoning: A global health issue-a report of multiple primary cancers. J Cutan Pathol 2007;34:203-6.

5. Ahmad S, Kitchin KT, Cullen WR. Arsenic species cause a release of ions from ferritin and the generation of activated oxygen. Arch Biochem Biophys 2000;382:195-202.

6. Sinha M, Manna PM, Sil PC. Arjunolic acid attenuates arsenic-induced nephrotoxicity. Pathophysiology 2008; 15:147-56.

7. Chatterjee M, Sil PC. Hepatoprotective effect of aqueous extract of Phyllanthus niruri on nimesulide-induced oxidative stress in vivo. Indian J Biochem Biophys 2006;43:299-305.

8. Shukla R, Kumar M. Role of panax ginseng as an antioxidant after cadmium-induced hepatic injuries. Food Chem Toxicol 2009;47:769-73

9. Hughes DA. Dietary antioxidants and human immune function. Nutr Bull 2000;25:35-41

10. Mukthi T, Seshamma S, Sailaja N. A mini-review on wheatgrass. J Pharmacogn Phytochem 2016;4:13-9.

11. Dholi UK. Phytochemical screening and estimation of the nutritional content of wheatgrass powder and wheatgrass juice. World J Pharm Res 2018;7:882-96.

12. Runjala S, Murthy YLN. Product development with wheatgrass and nutrient analysis. Int J Sci Res 2015;5:2319-7064.

13. Husain N, Trak TH, Chauhan D. Wheatgrass: Herbal remedy for health and beauty. Flora Fauna 2017;23:???

14. Suriyavathana M, Roopavathi I, Vijayan V. Phytochemical characterization of Triticum aestivum (Wheat Grass). J Pharmacogn Phytochem 2016;5:283-6.

15. Ferruzzi MG, Bohm V, Courtney PD, Schwartz SJ. Antioxidant and antimutagenic activity of dietary chlorophyll derivatives determined by radical scavenging and bacterial reverse mutagenesis assays. J Food Sci 2006;67:2589-95.

16. Carter O, Bailey GS, Dashwood RH. The dietary phytochemical chlorophyllin alters E-cadherin and beta-catenin expression in human colon cancer cells. J Nutr 2004;134 Suppl 12:34418-48

17. Negraes PD, Jordao BQ, Vicentini VE, Mantovani VS. Anticlastogenicity of chlorophyllin in the different cell cycle phases in cultured mammalian cells. Mutat Res 2004;557:177-82.

18. Cuendet M, Hostettmann K, Potterat O. Iridoid glucosides with free radical scavenging properties from Fagraea blumei. Helv Chim Acta 1997;80:1144-52.

19. Arya P, Kumar M. Chemoprevention by Triticum aestivum of mouse skin carcinogenesis induced by DMBA and croton oil-association with oxidative status. Asian Pac J Cancer Prev 2011;12:143-8.

20. Moron MJ, Depierre JW, Mannlrivik B. Levels of GSH GR and GST activities in rat lungs and liver. Biochem Biophys Acta 1979;582:67.

21. Ohkawa H, Ohishi N. Yagi K. Assay for lipid peroxidation in animal tissue by thio barbuturic acid reaction. Anal Biochem 1979;95:351-8.

22. Wroblewski F. Sigma Technical Bulletin No. 500; 1967.

23. Kind PR, King EJ. Estimation of plasma phosphate by determination of hydrolyzed phenol with anti-pyrine. J Clin Pathol 1954;7:322-6.

24. Reitman S, Frankel S. A colorimetric method for the determination of serum glutamic oxaloacetic and glutamic pyruvic transaminases. Am J Clin Pathol 1957;28:56-63.

25. Bourke GJ, Daly LE, Mc Gilvary JC. Interpretation and Uses of Medical Statistics. $3^{\text {rd }}$ ed. Oxford: Blackwell Scientific Publication; 1985.

26. Klibet F, Boumendjel A, Khiari M, Feki AE, Abdennour C, Messarah M. Oxidative stress-related liver dysfunction by sodium arsenite: Alleviation by Pistacia lentiscus oil. Pharm Biol 2016;54: 354-63.

27. Sharma A, Sharma MK, Kumar M. Protective effect of Mentha piperita against arsenic-induced toxicity in liver of Swiss albino mice. Basic Clin Pharmacol Toxicol 2007;100:249-57.

28. Dhar P, Jaitley M, Kalaivani M, Mehra RD. Preliminary morphological and histochemical changes in rat spinal cord neurons following arsenic ingestion. Neurotoxicology 2005;26:309-20.

29. Neiger RD, Osweiler GD. Effect of subacute low level dietary sodium arsenite on dogs. Fundam Appl Toxicol 1989;13:439-51.

30. Jadhav SH, Sarkar SN, Patil RD, Tripathi HC. Effects of subchronic exposure via drinking water to a mixture of eight water-contaminating metals: A biochemical and histopathological study in male rats. Arch Environ Contam Toxicol 2007;53:667-77.

31. Bashir S, Sharma Y, Irshad M, Gupta SD, Dogra TD. Arsenic-induced cell death in liver and brain of experimental rats. Basic Clin Pharmacol 
Toxicol 2006;98:38-43.

32. Liu J, Liu Y, Goyer RA, Achanzar W, Waalkes MP. Metallothionein-I/ II null mice are more sensitive than wild-type mice to the hepatotoxic and nephrotoxic effects of chronic oral or injected inorganic arsenicals. Toxicol Sci 2000;55:460-7.

33. Arteel GE, Guo L, Schlierf T, Beier JI, Kaiser JP, Chen TS, et al. Subhepatotoxic exposure to arsenic enhances lipopolysaccharideinduced liver injury in mice. Toxicol Appl Pharmacol 2008;226:128-39.

34. Gaim K, Gebru G, Abba S. The effect of arsenic on liver tissue of experimental animals (fishes and mice)-a review article. Int J Sci Res 2015;5:1-9.

35. Halliwell B, Chirico S. Lipid peroxidation: Its mechanism, measurement and significance. Am J Clin Nutr 1993;57:715S-25S.

36. Mylonas C, Kouretas D. Lipid peroxidation and tissue damage. In Vivo 1999;13:295-309.

37. Halliwell B. Free radicals and metal ions in health and disease. Proc Nutr Soc 1987;46:13-26.

38. Nieminen AL, Gores GJ, Wray BE, Tanaka Y, Herman B, Lemasters JJ. Calcium dependence of bleb formation and cell death in hepatocytes. Cell Calcium 1988;9:237-46.

39. Kuroda Y, Takeda K, Tabei K, Kuroki M, Yagimuma Y, Ohara T, et al. Role of $[\mathrm{Ca} 2+] \mathrm{i}$ in lethal oxidative injury in rat cultured inner medullary collecting duct cells. Pflugers Arch 1995;430:697-704.

40. Xu, M, Rui, D, Yan, Y, Xu S, Niu Q, Feng G, et al. Oxidative damage induced by arsenic in mice or rats: A systematic review and metaanalysis. Biol Trace Elem Res 2017;176:154-75.

41. Shimizu M, Hochadel JF, Fulmer BA, Waalkes MP. Effect of glutathione depletion and metallothionein gene expression on arsenic-induced cytotoxicity and c-myc expression in vitro. Toxicol Sci 1998;45:204-11.

42. Thompson DJ. A chemical hypothesis for arsenic methylation in mammals. Chem Biol Interact 1993;88:89-114.

43. El-Demerdash FM, Yousef MI, Radwan FM. Ameliorating effect of curcumin on sodium arsenite-induced oxidative damage and lipid peroxidation in different rat organs. Food Chem Toxicol 2008;47:249-54.

44. Ramos O, Carrizales L, Yanez L. Arsenic increased lipid peroxidation in rat tissues by a mechanism independent of glutathione levels. Environ Health Perspect 1995;103:85-8.

45. Sharma A, Sharma MK, Kumar M. Modulatory role of Emblica officinalis fruit extract against arsenic induced oxidative stress in Swiss albino mice. Chem Biol Interact 2009;180:20-30.

46. Repetto G, Sanz P, Repetto, M. Comparative in vitro effects of sodium arsenite and sodium arsenate on neuroblastoma cells. Toxicology 1994;92:143-53

47. Petrick JS, Ayala-Fierro F, Cullen W, Carter DE, Aposhian HV. Monomethyl arsonous acid (MMA (III)) is more toxic than arsenite in chang human hepatocytes. Toxicol Appl Pharmacol 2000;163:203-7.

48. Ayala-Fierro F, Baldwin AL, Wilson LM, Valeski JE, Carter DE. Structural alterations in the rat kidney after acute arsine exposure. Lab Invest 2000;80:87-97.

49. Fischer AB, Buchet JP, Lauwerys RR. Cellular metabolism of arsenic studied in mammalian cells in vitro. Environ Geochem Health 1989; $11: 87-92$.

50. Vandenberghe J. Hepatotoxicology: Mechanisms of liver toxicity and methodological aspects. In: Niesink JM, Vries JD, Hollinger MA, editors. Toxicology: Principle and Applications. ???: ???; 1951. p. 718.

51. Mandal N, Jal S, Mohanapriya K, Khora SS. Assessment of toxicity in puffer fish (Lagocephalus lunaris) from South Indian coast. Afr J Pharm Pharmacol 2013;7:2146-56.

52. Hardonk MJ, Koudstaal J. Enzyme Histochemistry as a Link between Biochemistry and Morphology. Stuttgart: Gustav Fischer; 1976. p. 40.

53. Modi M, Kaul RK, Kannan GM, Flora SJ. Co-administration of zinc and n-acetylcysteine prevents arsenic-induced tissue oxidative stress in male rats. J Trace Elem Med Biol 2006;20:197-204.

54. Ramaiah SK. A toxicologist guide to the diagnostic interpretation of hepatic biochemical parameters. Food Chem Toxicol 2007:45:1551-7.

55. Modi M, Flora SJ. Combined administration of iron and monoisoamylDMSA in the treatment of chronic arsenic intoxication in mice. Cell Biol Toxicol 2007;23:429-43.

56. Durairaj V, Hoda M, Shakya G, Babu SP, Rajagopalan R. Phytochemical screening and analysis of antioxidant properties of aqueous extract of wheatgrass. Asian Pac J Trop Med 2014;7S1:S398-404.

57. Jangle N, Padmanabhan P. Evaluation of phytochemicals, reducing power, antioxidant activity and in vitro lipid peroxidation activity of wheat grass juice. Int J Pharm Sci Res 2016;7:3436-40.

58. Asokh SA. Phytochemical and pharmacological screening of wheat grass juice (Triticum aestivum L.). Int J Pharm Sci Rev Res 2011;9:159-64.

59. Shakya G, Pajaniradje S, Hoda M, Durairaj V, Rajagopalan R. GCMS analysis, in vitro antioxidant and cytotoxic studies of wheatgrass extract. Am J Phytomed Clin Ther 2014;7:877-93.

60. Kulkarni SD, Acharya R, Rajurkar NS, Reddy AV. Evaluation of bioaccessibility of some essential trace elements from wheatgrass by in vitro digestion methods. Food Chem 2007;103:681-8.

61. Kulkarni SD, Acharya R, Nair AG, Rajurkar NS, Reddy AV. Determination of elemental concentration profiles in tender wheatgrass (Triticum aestivum L.) using instrumental neutron activation analysis. Food Chem 2006;95:699.

62. Kulkarni, SD. Studies on Tender Wheatgrass: Determination of Elemental Content, their Bioavailability and Antioxidant Activity, Ph.D. Thesis. Maharashtra: University of Pune; 2008.

63. Shakya G, Goud C, Pajaniradje C, Rajagopalan R. Protective role of Wheatgrass on oxidative stress in streptozotocin induced Type 2 diabetic rats. Int J Pharm Pharm 2012;4:415-23.

64. Bar-Sela G, Cohen M, Ben-Arye E, Epelbaum R. The medical use of wheatgrass: Review of the gap between basic and clinical applications. Mini Rev Med Chem 2015;15:1002-10.

65. Padalia S, Drabu S, Raheja I, Gupta A, Dhamija M, Surajmal M. Review article on multitude potential of wheatgrass juice (green blood): An overview. Chron Young Sci 2010;1:23-8

66. Chauhan M. A pilot study on wheat grass juice for its phytochemical, nutritional and therapeutic potential on chronic diseases. Int J Chem Stud 2014;2:27-34

67. Singh N, Verma P, Pandey BR. Therapeutic potential of organic Triticum aestivum Linn. (Wheat grass) in prevention and treatment of chronic diseases. Int J Pharm Sci Drug Res 2012;4:10-4.

68. Rana S, Kamboj JK, Gandhi V. Living life the natural way-wheatgrass and health (review article). Funct Foods Health Dis 2011;1:444-56.

69. Jain G, Jain N, Argal A. Wound healing potential of young leaves of Triticum aestivum on alloxan induced diabetic rats. Int J Pharm Pharm 2014;6:508-13.

70. Nepali S, Ki HH, Lee JH, Lee HY, Kim DK, Lee YM. Wheatgrassderived polysaccharide has antiinflammatory, anti-oxidative and antiapoptotic effects on LPS-induced hepatic injury in mice. Phytother Res 2017;31:1107-16.

71. Govind P. Medicinal plants against liver diseases. Int J Pharm Res 2011;2:115-21.

72. Suárez B, Álvarez AL, García YD, Barrio G, Lobo AP, Parra F. Phenolic profiles, antioxidant activity and in vitro antiviral properties of apple pomace. Food Chem 2010;120:339-42.

73. Lay MM, Karsani SA, Mohajer S, Malek SN. Phytochemical constituents, nutritional values, phenolics, flavonols, flavonoids, antioxidant, and cytotoxicity studies on Phaleria macrocarpa (Scheff.) Boerl fruits. BMC Complement Altern Med 2014;14:152.

74. Nimse SB, Pal D. Free radicals, natural antioxidants, and their reaction mechanisms. R Soc Chem 2015;5:27986-8006.

75. Rajoria A, Mehta A, Mehta P, Ahirwal L, Shukla S, Bajpai VK. Evaluation of antiproliferative and hepatoprotective effects of wheat grass (Triticum aestivum). Acta Biol Hung 2017;68:150-61. 